\title{
SYNTHESIS OF ZEOLITE NaA FROM LOW GRADE (HIGH IMPURITIES) INDONESIAN NATURAL ZEOLITE
}

\author{
Asalil Mustain, Gede Wibawa*, Mukhammad Furoiddun Nais, and Miftakhul Falah \\ Department of Chemical Engineering, Faculty of Industrial Technology, Sepuluh Nopember Institute of Technology (ITS), \\ Kampus ITS Sukolilo, Surabaya 60111, Indonesia
}

Received January 21, 2014; Accepted April 11, 2014

\begin{abstract}
The zeolite NaA has been successfully synthesized from the low grade natural zeolite with high impurities. The synthesis method was started by mixing natural zeolite powder with $\mathrm{NH}_{4} \mathrm{Cl}$ aqueous solution in the reactor as pretreatment. The use of pretreatment was to reduce the impurities contents in the zeolite. The process was followed by alkaline fusion hydrothermal treatment to modify the framework structure of natural zeolite and reduce the $\mathrm{SiO}_{2} / \mathrm{Al}_{2} \mathrm{O}_{3}$ ratio. Finally, the synthesized zeolite was calcined at $600{ }^{\circ} \mathrm{C}$ for $2 \mathrm{~h}$. The final zeolite product was characterized by $X$-ray fluorescence (XRF), X-ray diffraction (XRD) and scanning electron microscopy (SEM). The results showed that the morphology of the zeolite NaA was cubic shape as observed by SEM analysis and the synthesized zeolite $\mathrm{NaA}$ with pretreatment gave less impurity than without pretreatment.
\end{abstract}

Keywords: natural zeolite; zeolite NaA; synthesis; alkaline fusion; hydrothermal

\section{ABSTRAK}

Zeolit NaA telah berhasil disintesis dari zeolit alam kualitas rendah yang memiliki kandungan pengotor tinggi. Metode sintesis dimulai dengan mencampur serbuk zeolit alam dengan larutan $\mathrm{NH}_{4} \mathrm{Cl}$ dalam reaktor sebagai perlakuan awal. Kegunaan dari perlakuan awal ini adalah untuk menurunkan kandungan pengotor dalam zeolit. Proses dilanjutkan dengan perlakuan hidrotermal fusi alkali untuk memodifikasi struktur rangka dari zeolit alam dan menurunkan rasio $\mathrm{SiO}_{2} / \mathrm{Al}_{2} \mathrm{O}_{3}$. Akhirnya, zeolit tersintesis dikalsinasi pada $600{ }^{\circ} \mathrm{C}$ selama 2 jam. Produk zeolit akhir dikarakterisasi dengan $X$-ray fluorescence (XRF), X-ray diffraction (XRD) dan scanning electron microscopy (SEM). Hasil menunjukkan bahwa morfologi dari zeolit NaA adalah bentuk kubus seperti hasil observasi analisa SEM dan zeolit NaA tersintesis dengan perlakuan awal mempunyai pengotor yang lebih rendah daripada tanpa perlakuan awal.

Kata Kunci: zeolit alam; zeolit NaA; sintesis; fusi alkali; hidrotermal

\section{INTRODUCTION}

Indonesia has large potential reserves of natural zeolites because it lies within the ring of fire. At present, the zeolitic minerals in Indonesia, which have a potential deposit more than 400 million tons, have been explored. Clinoptilolite is the most abundant natural zeolite mainly found in a volcanogenic sedimentary rock [1]. Iron oxide, calcium oxide and quartz are usually present as impurities in the natural zeolite [2]. The specific impurities in the Indonesian zeolites are highly calcium oxide $(\mathrm{CaO})$ contents. The presence of impurities caused the pore clogging and covered the active sides of the natural zeolite surface [3]. These impurities should be removed to enhance the performance before it was utilized in the chemical process.

Zeolites were divided into two categories: natural and synthesized groups. In the last decade, zeolites have been gaining great attention and proved very

* Corresponding author. Tel/Fax : +62-31-5946240/5999282

Email address : gwibawa@chem-eng.its.ac.id useful in a wide range of applications. The natural zeolites were commonly used to remove heavy metal in water [4] and wastewater [5-6] treatment. Mostly, the synthesized zeolites were more valuable than the natural one. The uses of synthesized zeolites were particularly suitable as adsorbents in the alcohol purification [7-9] and esterification process [10-12]. The unique property of synthesized zeolite leads scientist to work in other possible area like as drug delivery systems in medical [13-16]. These possibilities allow zeolites to be material with great potential for many important applications.

The production of synthesized zeolite $\mathrm{NaA}$ using natural clinoptilolite has been studied in the previous work. The hydrothermal treatment was a preferred method that commonly used in the production process. Kamali et al. [17] synthesized zeolite NaA from natural clinoptilolite in a three stages hydrothermal procedure by using natural clinoptilolite as Si source and aluminum

Asalil Mustain et al. 
Table 1. Chemical composition of the natural zeolite in this study and another region

\begin{tabular}{|c|c|c|c|c|c|}
\hline \multirow{2}{*}{ Component } & \multicolumn{5}{|c|}{ Chemical composition of natural zeolite (wt\%) } \\
\hline & Indonesian $^{a}$ & Turkish $^{b}$ & Iranian $^{C}$ & Chilean $^{d}$ & Chinese $^{\epsilon}$ \\
\hline $\mathrm{Al}_{2} \mathrm{O}_{3}$ & 8.50 & 13.11 & 12.01 & 13.00 & 9.89 \\
\hline $\mathrm{SiO}_{2}$ & 69.80 & 69.31 & 66.03 & 67.00 & 65.52 \\
\hline $\mathrm{Na}_{2} \mathrm{O}$ & n.d..$^{f}$ & 0.52 & 2.10 & 2.60 & 2.31 \\
\hline $\mathrm{K}_{2} \mathrm{O}$ & 6.64 & 2.83 & 2.31 & 0.45 & 0.88 \\
\hline $\mathrm{CaO}$ & 5.81 & 2.07 & 3.20 & 3.20 & 3.17 \\
\hline $\mathrm{Fe}_{2} \mathrm{O}_{3}$ & 4.45 & 1.31 & 1.25 & 2.00 & 1.04 \\
\hline $\mathrm{MgO}$ & n.d. & 1.13 & 0.51 & 0.69 & 0.61 \\
\hline $\mathrm{MnO}$ & 0.07 & n.d. & n.d. & 0.04 & 0.06 \\
\hline $\mathrm{TiO}_{2}$ & 0.35 & n.d. & 0.27 & 0.20 & 0.21 \\
\hline $\mathrm{SiO}_{2} / \mathrm{Al}_{2} \mathrm{O}_{3}$ & 8.21 & 5.29 & 5.50 & 5.15 & 6.62 \\
\hline This work & ${ }^{\circ}$ Ref. [5] & [18] & & & \\
\hline
\end{tabular}

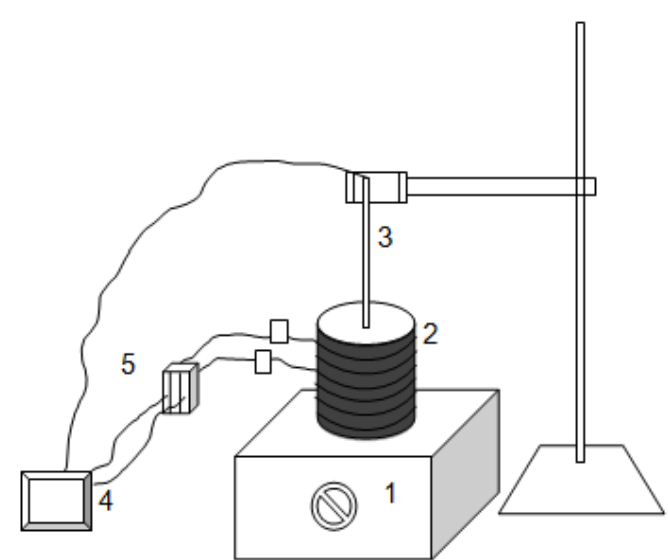

Fig 1. Schematic diagram of apparatus: (1) magnetic stirrer; (2) reactor equipped with electric heater; (3) thermocouple; (4) thermo control; (5) electric contactor

sulfate or sodium aluminate as Al source. In order to find a simple and fast method, Kazemian et al. [18] developed a synthesis of submicron zeolite LTA particles from natural clinoptilolite and industrial grade chemicals using one stage procedure. Since natural zeolite has a specific impurities depend on the mining location, the treatment of activation requires some modification based on the condition of the natural zeolite resources. Taffarel and Rubio [19] treated Chilean zeolites by chemical method using some solution and activation with $\mathrm{NH}_{4} \mathrm{Cl}$ at room temperature caused a decrease in $\mathrm{CaO}, \mathrm{MgO}$ and $\mathrm{K}_{2} \mathrm{O}$ composition.

The impurities contained in the synthesized zeolites and homogeneous product remained a problem to be overcome in the synthesis process. The aim of this study was to develop a synthesis method of low-grade natural zeolite with high impurities to produce synthesized zeolites $\mathrm{NaA}$ via alkaline fusion hydrothermal method. The effect of pretreatment and characterization of the product was also discussed as well.

\section{EXPERIMENTAL SECTION}

\section{Materials}

The low grade natural zeolite from Bandung (region of Indonesia) was used in the present study. The material was firstly washed with distilled water in order to remove all the soluble impurities. The sample was pulverized by using crusher, followed by screening process to give the particle size of $80-140$ mesh and then dried in the oven at $110{ }^{\circ} \mathrm{C}$. The chemical composition of the natural zeolite sample was estimated by using X-ray fluorescence (XRF) technique as presented in Table 1 together with the chemical composition of natural zeolite from another region as comparison. The results present that the impurities of Indonesian natural zeolite is higher than the comparing regions with the main impurities is $\mathrm{CaO}$ (5.81 wt\%). Meanwhile, the $\mathrm{CaO}$ content of commercial zeolite $\mathrm{A}$ is only about 2 wt\%. Ammonium chloride $\left(\mathrm{NH}_{4} \mathrm{Cl}\right)$, sodium hydroxide $(\mathrm{NaOH})$ and sodium aluminates $\left(\mathrm{NaAlO}_{2}\right)$ used in this study were produced by domestic company with industrial grade materials. $\mathrm{NH}_{4} \mathrm{Cl}$ aqueous solution from 1 to $2 \mathrm{~mol} \cdot \mathrm{L}^{-1}$ and $\mathrm{NaOH}$ aqueous solution $2 \mathrm{~mol} \cdot \mathrm{L}^{-1}$ were prepared with distilled water.

\section{Instrumentation}

The apparatus used in this study consists of 100 $\mathrm{ml}$ reactor equipped with stirrer, heater, and thermocouple. The temperature of the reactor was controlled by using thermo control (Transmitt G-7) with accuracy of $\pm 1^{\circ} \mathrm{C}$. The schematic diagram of the apparatus was shown in Fig. 1.

The chemical compositions of the samples were carried out by X-ray fluorescence (XRF) using PANalytical PW 4030 Spectrometer. X-ray Diffraction (XRD) patterns were obtained by using Philips X'Pert MPD diffractometer. The powder patterns were taken in the continuous mode with a $2 \theta$ range. $\mathrm{Cu} \mathrm{K \alpha}$ radiation 
Table 2. The effect of pretreatment on the final product of the synthesis process

\begin{tabular}{|c|c|c|c|c|c|}
\hline $\begin{array}{c}\text { Sample } \\
\text { Code }\end{array}$ & $\begin{array}{c}\mathrm{NH}_{4} \mathrm{Cl} \\
\left(\mathrm{mol} \cdot \mathrm{L}^{-1}\right)\end{array}$ & $\begin{array}{c}\text { Agitation Time } \\
\text { (h) }\end{array}$ & $\mathrm{SiO}_{2} / \mathrm{Al}_{2} \mathrm{O}_{3}$ & $\begin{array}{l}\mathrm{CaO} \\
\text { (wt\%) }\end{array}$ & Crystallinity phase \\
\hline $\mathrm{ZN}$ & \multicolumn{2}{|c|}{ Natural Zeolites } & 8.21 & 5.81 & $\mathrm{C}^{1}+\mathrm{M}^{2}$ \\
\hline Z0 & - & - & 1.74 & 5.06 & $Z^{3}$ \\
\hline Z1 & \multirow{3}{*}{1} & 12 & 2.02 & 2.54 & ZA \\
\hline $\mathrm{Z2}$ & & 16 & 1.92 & 4.39 & $\mathrm{ZA}$ \\
\hline Z3 & & 20 & 2.04 & 2.38 & ZA \\
\hline Z4 & \multirow{3}{*}{1.5} & 12 & 1.93 & 2.16 & $\mathrm{ZA}$ \\
\hline Z5 & & 16 & 1.96 & 4.55 & $\mathrm{ZA}$ \\
\hline Z6 & & 20 & 2.00 & 3.36 & ZA \\
\hline $\mathrm{Z7}$ & \multirow{3}{*}{2} & 12 & 1.94 & 2.42 & ZA \\
\hline Z8 & & 16 & 1.97 & 2.16 & $\mathrm{ZA}$ \\
\hline Z9 & & 20 & 1.90 & 3.13 & ZA \\
\hline
\end{tabular}

Table 3. Chemical composition of the natural zeolite, synthesized zeolite (Z4) and commercial zeolite A by mean of XRF

\begin{tabular}{cccc}
\hline Component & $\begin{array}{c}\text { Natural Zeolite } \\
(w t \%)\end{array}$ & $\begin{array}{c}\text { Synthesized Zeolite; Z4 } \\
(w t \%)\end{array}$ & $\begin{array}{c}\text { Commercial Zeolite A } \\
(w t \%)\end{array}$ \\
\hline $\mathrm{Al}_{2} \mathrm{O}_{3}$ & 8.5 & 30.3 & 26 \\
$\mathrm{SiO}_{2}$ & 69.8 & 58.6 & 39.3 \\
$\mathrm{~K}_{2} \mathrm{O}$ & 6.64 & 4.35 & 24.2 \\
$\mathrm{CaO}$ & 5.81 & 2.16 & 2.19 \\
$\mathrm{Fe}_{2} \mathrm{O}_{3}$ & 4.45 & 3.99 & 3.41 \\
$\mathrm{TiO}_{2}$ & 0.35 & 0.33 & 0.42 \\
$\mathrm{~V}_{2} \mathrm{O}_{5}$ & 0.008 & 0.04 & 0.02 \\
$\mathrm{MnO}$ & 0.071 & 0.084 & 0.067 \\
$\mathrm{CuO}$ & 0.03 & 0.047 & 0.047 \\
$\mathrm{BaO}$ & 0.07 & 0.08 & 0.09 \\
$\mathrm{SiO}_{2} / \mathrm{Al}_{2} \mathrm{O}_{3}$ & 8.21 & 1.93 & 1.51 \\
\hline
\end{tabular}

was used with the tube operated at $40 \mathrm{kV}$ and $30 \mathrm{~mA}$. PANalytical X'Pert HighScore software was used to confirm the crystallinity phase of the samples from the powder patterns. The particle morphology of the synthesized zeolites were investigated by scanning electron microscopy (SEM) analysis, performed by using Carl Zeiss EVO MA10 instrument. To avoid surface charging, samples were coated with gold under vacuum prior to analysis.

\section{Procedure}

The process was started by mixing $5 \mathrm{~g}$ of natural zeolite powder with $100 \mathrm{ml}$ of $\mathrm{NH}_{4} \mathrm{Cl}$ aqueous solution from 1 to $2 \mathrm{~mol} \cdot \mathrm{L}^{-1}$ and stirred from 12 to $20 \mathrm{~h}$ in the reactor at room temperature as pretreatment. Pretreatment was intended to reduce the impurities contents in the natural zeolite. The resulting material was filtered and dried at $110{ }^{\circ} \mathrm{C}$ for $10 \mathrm{~h}$. The process was followed by alkaline fusion hydrothermal treatment to modify the framework structure of natural zeolite. The process was carried out by mixing the preceding material with $90 \mathrm{~mL}$ of $\mathrm{NaOH}$ aqueous solution $2 \mathrm{~mol} \cdot \mathrm{L}^{-1}$ and $6.13 \mathrm{~g}$ (stoichiometric calculation) of sodium aluminates under magnetic stirring in the reactor at
$80{ }^{\circ} \mathrm{C}$ for $8 \mathrm{~h}$. The final synthesis solution was filtered, washed with distilled water and then dried in the oven at $110{ }^{\circ} \mathrm{C}$ for $10 \mathrm{~h}$. Finally, the product was calcined in the furnace at $600{ }^{\circ} \mathrm{C}$ for $2 \mathrm{~h}$ to remove the occluded organics from inside the zeolite pore space.

\section{RESULT AND DISCUSSION}

The chemical composition and the cristallinity phase of each sample by means of XRF and XRD analysis are given in Table 2 . The results show that the $\mathrm{CaO}$ content in the synthesized zeolite significantly decreased after the synthesis process. The $\mathrm{SiO}_{2} / \mathrm{Al}_{2} \mathrm{O}_{3}$ ratio can also be reduced in the range of $1.7-2$ and zeolite $\mathrm{NaA}$ is the predominant crystallinity phase in the sample product. Due to the $\mathrm{SiO}_{2} / \mathrm{Al}_{2} \mathrm{O}_{3}$ ratio of several samples of zeolite $\mathrm{NaA}$ are in the range of 1.4-2.2, the $\mathrm{SiO}_{2} / \mathrm{Al}_{2} \mathrm{O}_{3}$ ratio of the natural zeolites in this work $(=8.21$, as shown in Table 2$)$ must be reduced by adding appropriate amounts of sodium aluminate in the alkaline medium provided by sodium hydroxide as mineralizing agent. The synthesis process of zeolite $\mathrm{NaA}$ from natural zeolite in this study based on the following mechanisms [18],

$\mathrm{NaAlO}_{2}+2 \mathrm{H}_{2} \mathrm{O} \rightarrow \mathrm{NaAl}(\mathrm{OH})_{4}$ 


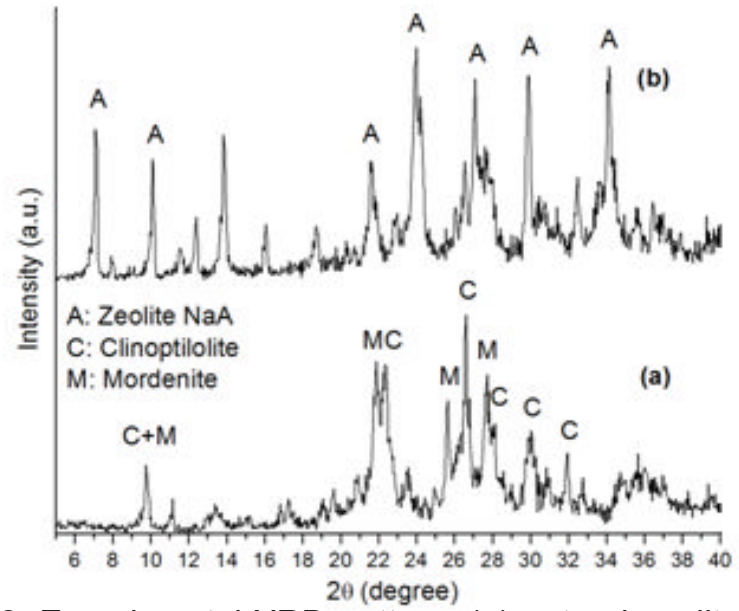

Fig 2. Experimental XRD pattern: (a) natural zeolite and (b) synthesized zeolite $\mathrm{NaA}$

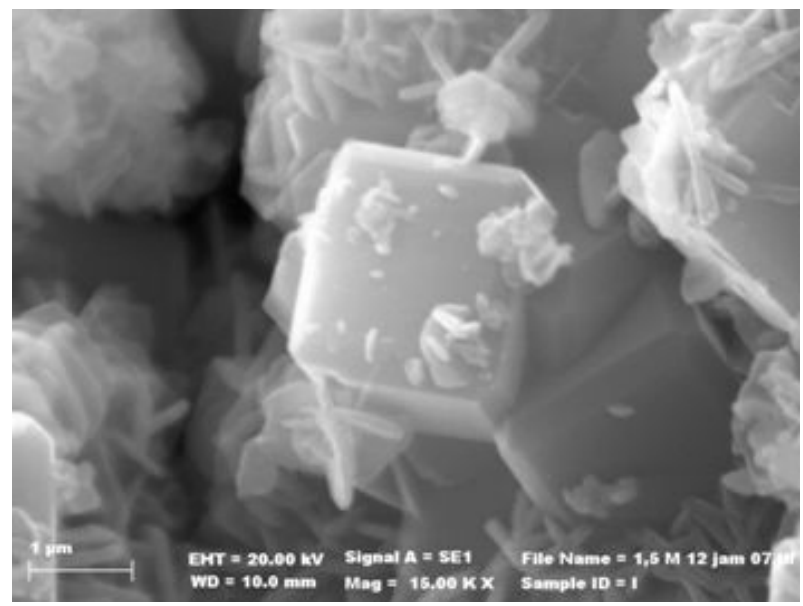

Fig 4. SEM image of the synthesized zeolite NaA

$2 \mathrm{Na}_{6}\left[\left(\mathrm{AlO}_{2}\right)_{6}\left(\mathrm{SiO}_{2}\right)_{30}\right] \cdot n \mathrm{H}_{2} \mathrm{O}+48 \mathrm{NaAl}(\mathrm{OH})_{4} \rightarrow 5 \mathrm{Na}_{12}\left[\left(\mathrm{AlO}_{2}\right)_{12}\left(\mathrm{SiO}_{2}\right)_{12}\right] \cdot m \mathrm{H}_{2} \mathrm{O}$

The best product obtained from this process was sample $\mathrm{Z4}$ because of natural zeolite with $\mathrm{SiO}_{2} / \mathrm{Al}_{2} \mathrm{O}_{3}$ ratio of 8.21 was converted to zeolite $\mathrm{NaA}$ with $\mathrm{SiO}_{2} / \mathrm{Al}_{2} \mathrm{O}_{3}$ ratio of 1.93 and $\mathrm{CaO}$ impurities might also be reduced from $5.81 \mathrm{wt} \%$ to $2.16 \mathrm{wt} \%$ by the addition of $1.5 \mathrm{~mol} \cdot \mathrm{L}^{-1}$ $\mathrm{NH}_{4} \mathrm{Cl}$ and agitation time of $12 \mathrm{~h}$.

Alkaline fusion hydrothermal treatment without the addition of $\mathrm{NH}_{4} \mathrm{Cl}$, which in this case is sample $\mathrm{ZO}$, shows that $\mathrm{CaO}$ contents in this product remain high as in the natural zeolite. In the synthesis process with or without the addition of $\mathrm{NH}_{4} \mathrm{Cl}$, zeolite $\mathrm{NaA}$ can be produced. However, the product of the process without the addition of $\mathrm{NH}_{4} \mathrm{Cl}$ still contains high $\mathrm{CaO}$ impurities. The developed pretreatment in this study is advantageous because the $\mathrm{SiO}_{2} / \mathrm{Al}_{2} \mathrm{O}_{3}$ ratio is still around 2 (low ratio) and it doesn't change the framework structure of the zeolite products with alkaline fusion hydrothermal treatment. Moreover, it is also able to reduce the $\mathrm{CaO}$ impurities [19].

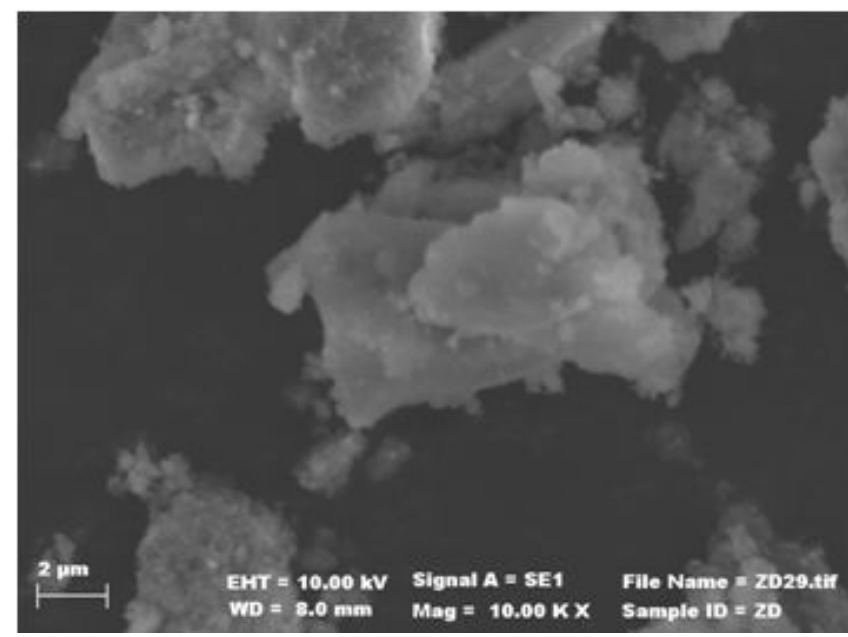

Fig 3. SEM image of the natural zeolite

The chemical composition of the natural zeolite, synthesized zeolite (Z4) and commercial zeolite A are presented together in Table 3 . In these results, the $\mathrm{Al}_{2} \mathrm{O}_{3}$ content of the synthesized zeolite significantly increased to $30.3 \mathrm{wt} \%$ in comparison to the parent natural zeolite (i.e. $8.5 \mathrm{wt} \%$ ) due to the addition of sodium aluminates in the synthesis process. These results are revealed that the synthesized zeolite (Z4) has similar compositions with the commercial zeolite $\mathrm{A}$. The differences are only in the observed $\mathrm{K}_{2} \mathrm{O}, \mathrm{SiO}_{2}$, and $\mathrm{Al}_{2} \mathrm{O}_{3}$ contents, but the value of $\mathrm{SiO}_{2} / \mathrm{Al}_{2} \mathrm{O}_{3}$ ratio is quite similar. In addition, the main components of zeolite, which are $\mathrm{SiO}_{2}$ and $\mathrm{Al}_{2} \mathrm{O}_{3}$ contents, in the synthesized zeolite $\mathrm{NaA}$ are higher than the commercial one. From a chemical composition point of view, the developed process in this study is advantage as the total amount of $\mathrm{SiO}_{2}$ and $\mathrm{Al}_{2} \mathrm{O}_{3}$ in the product are approximately $88.9 \mathrm{wt} \%$.

The XRD measured pattern of the raw natural zeolite is shown in Fig. 2a. According to this result, clinoptilolite $\left(2 \theta=9.83^{\circ}, 22.37^{\circ}, 26.05^{\circ}, 28.17^{\circ}, 30.00^{\circ}\right.$, $\left.32.01^{\circ}\right)$ and mordenite $\left(2 \theta=9.76^{\circ}, 22.21^{\circ}, 25.58^{\circ}\right.$, $\left.27.68^{\circ}\right)$ phases were observed. Fig. $2 b$ shows the experimental pattern of the synthesized zeolite (Z4) and it clearly presents that the product of the synthesized zeolite in this study belongs to zeolite $\mathrm{NaA}$ $\left(2 \theta=7.18^{\circ}, 10.16^{\circ}, 21.65^{\circ}, 23.97^{\circ}, 27.09^{\circ}, 29.92^{\circ}\right.$, $34.16^{\circ}$ ) as indicated by the position of the peak patterns. The crystallographic parameters of the zeolite $\mathrm{NaA}$ are the cubic crystal system and the space group Fm3c with the lattice parameters $\mathrm{a}=\mathrm{b}=\mathrm{c}=24.61 \AA$ and $\alpha=\beta=\gamma=90^{\circ}$ [20].

SEM micrograph of the natural zeolite and synthesized zeolite (Z4) are illustrated in Fig. 3 and 4, respectively. From these micrographs, the sharp edged natural zeolite can be converted into zeolite $\mathrm{NaA}$ which has smoothed morphology. The raw zeolite, with an 
average size of approximately $5 \mu \mathrm{m}$, forms the narrow size distribution particles with an average size of approximately $2 \mu \mathrm{m}$ after the synthesis process. SEM image of the synthesized zeolite $\mathrm{NaA}$ shows the cubic morphology of the material, which agrees with the previous literature data [21].

\section{CONCLUSION}

The developed pretreatment for alkaline fusion hydrothermal method was successfully reduced the impurities content in the synthesized zeolite. From this process, high impurities natural zeolite with $\mathrm{SiO}_{2} / \mathrm{Al}_{2} \mathrm{O}_{3}$ ratio of 8.21 was capable to be converted to zeolite $\mathrm{NaA}$ with $\mathrm{SiO}_{2} / \mathrm{Al}_{2} \mathrm{O}_{3}$ ratio of 1.93 and less $\mathrm{CaO}$ impurities (2.16 wt\%). SEM result shows that the average particle size of the product was approximately $2 \mu \mathrm{m}$. From a chemical composition point of view, the developed process in this study was advantage due to the high $\mathrm{SiO}_{2}$ and $\mathrm{Al}_{2} \mathrm{O}_{3}$ contents in the product.

\section{ACKNOWLEDGEMENT}

This research was supported by research grant of Sepuluh Nopember Institute of Technology (ITS) under Contract No: 0750.253/I2.7/PM/2011.

\section{REFERENCES}

1. Wang, S., and Peng, Y., 2010, Chem. Eng. J., 156 (1), 11-24.

2. Boukadir, D., Bettahar, N., and Derriche, Z., 2002, Ann. Chim. Sci. Mat., 27 (4), 1-13.

3. Athanasiadis, K., and Helmreich, B., 2005, Water Res., 39 (8), 1527-1532.

4. Doula, M.K., 2006, Water Res., 40 (17), 3167-3176.

5. Erdem, E., Karapinar, N., and Donat, R., 2004, J. Colloid Interface Sci., 280 (2), 309-314.

6. Faghihian, H., Marageh, M.G., and Kazemian, H., 1999, Appl. Radiat. Isot., 50 (4), 655-660.

7. Caro, J., Noack, M., and Kölsch, P., 2005, Adsorption, 11 (3-4), 215-227.
8. Kondo, M., Yamamura, T., Yukitake, T., Matsuo, Y., Kita, H., and Okamoto, K., 2003, Sep. Purif. Technol., 32 (1-3), 191-198.

9. Morigami, Y., Kondo, M., Abe, J., Kita, H., and Okamoto, K., 2001, Sep. Purif. Technol., 25 (1-3), 251-260.

10. Ameri, E., Moheb, A., and Roodpeyma, S., 2010, Chem. Eng. J., 162 (1), 355-363.

11. de la Iglesia, Ó., Mallada, R., Menéndez, M., and Coronas, J., 2007, Chem. Eng. J., 131 (1-3), 3539.

12. Li, W., Liu, W., Xing, W., and Xu, N., 2013, Ind. Eng. Chem. Res., 52 (19), 6336-6342.

13. Amorim, R., Vilaça, N., Martinho, O., Reis, R.M., Sardo, M., Rocha, J., Fonseca, A.M., Baltazar, F., and Neves, I.C., 2012, J. Phys. Chem. C, 116 (48), 25642-25650.

14. Braschi, I., Gatti, G., Paul, G., Gessa, C.E., Cossi, M., and Marchese, L., 2010, Langmuir, 26 (12), 9524-9532.

15. Braschi, I., Blasioli, S., Gigli, L., Gessa, C.E., Alberti, A., and Martucci, A., 2010, J. Hazard. Mater., 178 (1-3), 218-225.

16. Martucci, A., Pasti, L., Marchetti, N., Cavazzini, A., Dondi, F., and Alberti, A., 2012, Microporous Mesoporous Mater., 148 (1), 174-183.

17. Kamali, M., Vaezifar, S., Kolahduzan, H., Malekpour, A., and Abdi, M.R., 2009, Powder Technol., 189 (1), 52-56.

18. Kazemian, H., Modarress, H., Kazemi, M., and Farhadi, F., 2009, Powder Technol., 196 (1), 22-25.

19. Taffarel, S.R., and Rubio, J., 2009, Miner. Eng., 22 (4), 336-343.

20. Gramlich, V., and Meier, W.M., 1971, Z. Kristallogr. Kristallgeom. Kristallphys. Kristallchem., 133 (1), 134-149.

21. Loiola, A.R., Andrade, J.C.R.A., Sasaki, J.M., and da Silva, L.R.D., 2012, J. Colloid Interface Sci., 367 (1), 34-39.

22. Englert, A.H., and Rubio, J., 2005, Int. J. Miner. Process., 75 (1-2), 21-29.

23. Wang, Y., and Lin, F., 2009, J. Hazard. Mater., $166(2-3), 1014-1019$. 